\title{
The Moral Source of the Kantian Sublime
}

\author{
Melissa McBay Merritt
}

We see other worlds in the distance, but gravity forces us to remain on the earth; we can see other perfections in the spirits above us, but our nature forces us to remain human beings. ${ }^{1}$

\section{INTRODUCTION}

A distinctive feature of Kant's account of the sublime is that the term "sublime" does not properly apply to any object in nature: no craggy peak, turbulent sea, or thunderous sky is sublime sensu stricto. Rather, "true sublimity must be sought only in the mind of one who judges, not in the object in nature."2 Indeed, no sensible object - be it St. Peter's or the Matterhorn - is truly sublime. Such a thing may be dubbed "sublime" only by courtesy, just inasmuch as it "awakens a feeling of a supersensible faculty in us" (CJ 5:250). Only a state of mind can truly be sublime (CJ 5:245-6, 257, and 264). Any account of the Kantian sublime must examine and account for this state of mind. Kant likens the sublime state of mind to a "vibration, i.e., to a rapidly alternating repulsion from, and attraction to, one and the same object" (CJ 5:258; see also CJ 5:245). But this clue about the phenomenology of the sublime does not adequately specify this state of mind, because other states of mind, such as weakness of will, might be described in similar terms.

In order to specify the sublime state of mind appropriately, we need to appreciate the significance of the sublime in the broader scope of Kant's critical project. ${ }^{3}$ The received view which Kant analyzes and corrects rather than dismisses outright - was that the sublime refers to something great or mighty in nature or art that arouses a distinctive pleasure in the subject. The pleasure is distinctive because it is mixed with a measure of pain or fear. In the Critique of the Power of Judgment, Kant explicitly acknowledges Edmund Burke's A Philosophical Inquiry into the Origin of Our Ideas of the Sublime and Beautiful. ${ }^{4}$ Burke traces our enjoyment of the

\footnotetext{
I The epigraph is a remark from notes Kant inserted into his own copy of Beobachtungen über das Gefühl des Schönen und Erhabenen (Observations on the Feeling of the Beautiful and Sublime) sometime after its publication in I764. See Kant's gesammelte Schriften, Königlichen Preussischen (later Deutschen) Akademie der Wissenschaften, 29 vols. (Berlin: Reimer [later de Gruyter], I900-), vol. 20 (KGS); Notes and Fragments, ed. Paul Guyer; trans. Curtis Bowman, Paul Guyer, and Frederick Rauscher (Cambridge: Cambridge University Press, 2005), 20:I53. References to all of Kant's works (with the exception of the Critique of Pure Reason) are to volume and page of the Akademie edition.

${ }^{2}$ Kritik der Urteilskraft, KGS 5; Critique of the Power of Judgment, ed. Paul Guyer; trans. Paul Guyer and Eric Matthews (Cambridge: Cambridge University Press, 2000), 5:256 (CJ)

3 As we will see, Kant discusses the sublime in a variety of contexts. I focus here on Kant's "critical-period" (i.e., postI78I) view of the sublime. I have relatively little to say about the precritical Observations, a putatively descriptive catalog of the "beautiful" and "sublime" qualities of human beings according to sex, nationality, and race.

${ }_{4}$ Kant discusses the empirical approach of the British tradition and quotes twice from Burke's work, which he read in translation (see CJ 5:277 and the first introduction to Critique of the Power of Judgment, 20:238). The burgeoning
} 
sublime in nature to the "passions" related to self-preservation. Whatever can "excite the ideas of pain, and danger," he maintains, “... whatever is in any sort terrible, ... or operates in a manner analogous to terror, is a source of the sublime." 5 We must respond viscerally to the idea of a physical threat on our existence, while at the same time recognizing our real safety from it. For if we really were in pain or danger, we would simply move to escape the threat. But then we would not be in any position to savor the passions of "pain and danger" - passions Burke takes to be the most powerful that we are capable of feeling. He thus implies that the sublime makes available to reflection a fundamental impulse of our animal nature.

Kant learns from this that the sublime might be pressed into service for a reflective, or selfexamining, philosophy. ${ }^{6}$ For Kant, however, our enjoyment of the sublime in nature makes available to reflection something about our essence as rational beings, not our instincts as animal beings. For Kant takes up the sublime under the rubric of his critical philosophy, that is, the collective work of the three Critiques, a project that (in broadest overview) is concerned with the nature of human reason. Admittedly, the theory of the sublime does not directly contribute to what is arguably the central task of the critical project, to establish fundamental principles of rational cognition. ${ }^{7}$ The sublime instead contributes to the reflective work of critical philosophy by illuminating the moral psychology of the rational animal. Kant conceives of human nature according to this ancient formula and claims that our appreciation of the sublime in the sensible world has its "foundation in human nature," and, specifically, in our propensity to be affected by "practical" or "moral" ideas of reason (CJ 5:262; 5:265).

However, although Kant insists on the moral source of the sublime in the Critique of Judgment, he provides little in the way of an actual account. The reader is left to connect the dots between the sublime as it figures in Kant's aesthetics and the sublime as it figures in his moral philosophy. My aim in this chapter is to show how this connection is to be drawn and thereby to demonstrate that the sublime has greater, and more pervasive, significance for Kant's critical philosophy than is commonly supposed. ${ }^{8}$

I begin with the aesthetic theory, showing how Kant attributes the characteristic "vibration" to the conflicting directives of our capacity to represent sensible things (imagination) versus

industry of travelogues provided another source for the received view: Kant mentions Claude-Étienne Savary's Lettres sur L'Égypte (CJ 5:252) and Horace Bénédict de Saussure's Voyage dans les Alps (CJ 5:265 and 276).

5 Edmund Burke, A Philosophical Enquiry into the Origin of Our Ideas of the Sublime and Beautiful, ed. James T. Boulton (London: Routledge and Kegan Paul, I958 [1757]), I.7.39.

${ }^{6}$ By that I simply mean a philosophical project in which the human mind examines itself. Although many of the canonical works of early modern philosophy are presented in such terms, for Kant a reflective philosophy is one in which human reason examines its own cognitive capacity: see Kritik der reinen Vernunft, KGS 3 and 4; Critique of Pure Reason, trans. Paul Guyer and Allen W. Wood (Cambridge: Cambridge University Press, I999), Axi and Bxxxv, see also A877/B849. All references are to the pagination of the first (I78I) and second (I787) Akademie editions, abbreviated CPR A/B.

7 For this reason, the Analytic of the Sublime is offered as a mere "appendix" to the Analytic of the Beautiful; it does not directly contribute to the overall project of the Critique of the Power of Judgment (CJ 5:246). Kant finds in the judgment of taste - our appreciation of the beautiful rather than the sublime - the resources to ground the teleological view of nature that he in turn supposes must be invoked to bridge a "gulf" between nature and freedom, and hence to unify theoretical and practical reason (see CJ 5:I75-6ff.).

${ }^{8}$ Most commentators on the Kantian sublime focus almost exclusively on the sublime in nature and overlook the moral sublime. For exceptions to this general rule, see Paul Guyer, "Symbols of Freedom in Kant's Aesthetics," in Values of Beauty: Historical Essays in Aesthetics (Cambridge: Cambridge University Press, 2005), 222-4I, who addresses aspects of the connection; Paul Crowther, The Kantian Sublime: From Morality to Art (Oxford: Clarendon Press, I989), who gives attention to the moral context of Kant's sublime, although he has little say about its bearing on the sublimity of nature; and Malcolm Budd, The Aesthetic Appreciation of Nature (Oxford: Oxford University Press, 2002), who notes Kant's suggestion that our enjoyment of the sublimity of nature might give rise to "a vivid consciousness of a respect in which we are sublime, a feeling of our own sublimity as rational agents." Budd does not explore the issue, however, and chalks up Kant's suggestion of a moral source for the sublime to his "inveterate tendency ... to moralize, in one way or another, any experience that he valued" (see pp. 68 and 84). 
our capacity to represent the supersensible (reason). A sublime state of mind is one in which we take pleasure in the failure of sensible representation, because this failure enables us to appreciate the power of reason to conceive of what can never be met with in the senses, or rendered in sensible representation. I then show how the struggle between imagination and reason in Kant's aesthetic theory has its roots in his conception of a conflict fundamental to human nature - a conflict that cannot be overcome as long as we are both rational and animal. We are, in Kant's view, simultaneously repulsed by the demands of morality and yet attracted to the ideal of perfect rationality that can only be conceived through the moral law. According to Kant, sound moral disposition exercises a certain sublimity of mind, one that is analogous to the aesthetic response to the sublime in nature. Thus my aim is to show how we can understand the Kantian sublime by tracing it to its roots in the moral psychology of the rational animal.

\section{THE SUBLIME IN NATURE}

The Analytic of the Sublime in the Critique of the Power of Judgment deals primarily with the representation of the sublime in nature. Kant sets out with a general explication of the sublime as that which is "absolutely great" or "great beyond all comparison" (CJ 5:248). He then distinguishes the "mathematical" from the "dynamical" sublime: the former concerns what is great in spatial extension; the latter what is great in power. ${ }^{9}$

Kant's account of the mathematical sublime begins with a discussion of ordinary measurement, or the determination of magnitude according to a fixed and repeatable unit. There is always an appropriate standard of measurement for anything that we can encounter in space: not even the breadth of a galaxy is absolutely great (CJ 5:250). Thus ordinary measurement, which Kant refers to as the "logical estimation of magnitude," is inherently comparative (CJ $5: 248$ ). For this reason, it is not a candidate for the sublime, because the sublime is the representation of something as great beyond all comparison.

The mathematical sublime instead exercises an "aesthetic" estimation of magnitude, as when we take in the size of something merely by eye (CJ 5:25I). An object can be represented as sublime when a subject attempts an aesthetic estimation of its magnitude and finds that it is beyond her capacity. Much of this rests, as Kant points out, on the subject's vantage point. The subject needs to stand in a sweet spot: she must not stand so close to the object that she takes in only a mass that spreads on all sides, extending into and filling her peripheral vision, but she must not stand so far that the boundaries of the entire object easily register in a single glance. In the sweet spot, the subject struggles to attain a comprehensive view of the thing but just fails managing only to have parts in view as others fall out of view. Kant attributes this failure to the power of the imagination, or the capacity to represent sensible particulars. With the exercise of the imagination, the subject is able to "apprehend," or take in, the object bit by bit, but she cannot "comprehend" the object, or represent it as a whole (CJ 5:25I-2). Thus it feels to the subject as if the apprehension would need to go on ad infinitum if the magnitude of the object were ever to be represented as a comprehensive whole. However, we are unable to represent an infinitely extensive, yet comprehensive, magnitude in sensible representation; anything that we can represent as a whole by means of the senses has boundaries in our sensory field. The representation of the "given infinite" (CJ 5:254), or "infinity comprehended" (CJ 5:255), can only be an idea of reason, that is, an intellectual representation to which no sensible representation can ever be adequate. Thus the mathematical sublime brings to light our capacity to represent the supersensible, which is reason.

\footnotetext{
${ }^{9}$ For insightful discussions of the distinction between the mathematical and dynamical sublime, see Crowther, The Kantian Sublime, 4I-I35, and Paul Guyer, Kant and the Experience of Freedom: Essays on Aesthetics and Morality (Cambridge: Cambridge University Press, I996), I87-228.
} 
In the dynamical sublime, the greatness is one of power: we find it in "threatening cliffs, thunder clouds towering up into the heavens, bringing with them flashes of lightning and crashes of thunder, volcanoes with their all-destroying violence, hurricanes with the devastation they leave behind, the boundless ocean set into a rage, a lofty waterfall on a mighty river" (CJ 5:26I). We must represent the object as "fearful" - capable of arousing fear in us - without our actually being afraid of it. For if the subject were actually afraid, the impulse to avoid further engagement with the object would take hold. To represent the object as sublime, the subject must be able to dwell on the representation of a physical force incomparably greater than any she finds in herself. The subject who is able to contemplate a threat to her physical existence - without fleeing, as it were, from the representation of it - thereby finds within herself grounds for supposing that she is in some respect "independent of" this threat, or in some way superior to nature (CJ 5:26I). The dynamical sublime brings to light "a self-preservation of quite another kind than that which can be threatened and endangered by nature outside us" (CJ 5:26I-2).

Let us consider now what is common to the mathematical and the dynamical sublime. As I noted at the outset, Kant characterizes the sublime state of mind as "a rapidly alternating repulsion from and attraction to one and the same object" (CJ 5:258). Although this gloss appears in the discussion of the mathematical sublime, it would evidently hold for the dynamical sublime as well, in which, if anything, the aspect of repulsion is easier to identify. Because we naturally avoid physical threats, the representation of a physical threat would be repulsive even if we recognize our safety and engage in no real avoidance. In the case of the mathematical sublime, the difficulty of taking in the object figures as a kind of threat on our ability to make sense of the physical world around us: this is fearful and thus would introduce the element of repulsion. Both the mathematical and the dynamical sublime involve the representation of a threat on our physical capacities, broadly understood.

But Kant is vague about the attractive aspect of the sublime in the Critique of the Power of Judgment. He tells us that we are attracted to the large or mighty object in nature, but only because it stands in for an attraction to "the idea of humanity" in ourselves (CJ 5:257). Kant offers a further clue when he remarks that such large or powerful things are potentially useful, because the representation of them can "make palpable in ourselves a purposiveness that is entirely independent of nature" (CJ 5:246; see also 5:259). By "a purposiveness ... independent of nature," Kant indicates that we are determined toward some end other than animal selfpreservation; the enjoyment of the sublime in nature apparently helps us to appreciate this end, or reinforces an existing appreciation of it. Kant reformulates this point when he claims that the enjoyment of the sublime arouses a certain "feeling" for our "supersensible vocation" (CJ 5:257). He later identifies this as "moral feeling": a feeling for the "vocation of the mind" that "entirely oversteps the domain of [nature]" (CJ 5:268). He even claims that this "vocation" is itself "sublime" (CJ 5:264; see also 5:262). We must ascertain what Kant is gesturing toward with these remarks in order to have an adequate account of his conception of the sublime. Hence the Critique of the Power of Judgment cannot be our sole text for interpreting the Kantian sublime, because it fails to explain the attractive aspect of the sublime.

To understand what Kant is saying here about moral feeling and our sublime "vocation," we need to consider his view of human nature - or, to be more specific, the moral psychology of the rational animal. However, we must first get a clearer view of the distinction between the sensible and the supersensible that is at work in Kant's theory of the sublime. We will then be in a better position to make sense of Kant's remarks about our "sublime" or "supersensible vocation" as rational beings. To understand Kant's distinction between the sensible and the supersensible, we must take a step back and consider it in light of the broader aims of Kant's critical philosophy. 


\section{THE SENSIBLE AND THE SUPERSENSIBLE}

Although Kant's theory of the sublime does not contribute directly to the epistemological aims of critical philosophy, it cannot be understood in abstraction from those aims. So we must begin with Kant's famous lament about the "peculiar fate" of human reason: it is "burdened by questions" that it is neither able to ignore nor able to answer (CPR Avii). Kant has in mind the classic problems of metaphysics, such as the attempt to demonstrate the existence of God, the immortality of the soul, and the freedom of the will. Like most philosophers of the modern era, Kant addresses the challenges of metaphysics by providing first an assessment of the limits of our cognitive capacity. Unlike many of his predecessors, however, Kant does not set out to suppress reason's irksome tendency to raise questions that it cannot answer. Instead, Kant advocates finding a way of handling these questions that respects their rational origin and epistemological significance - while guarding against being led by them into speculative temptation, and thereupon into error.

For Kant, handling these questions properly requires maintaining a clear distinction between two modes of knowledge: the theoretical and the practical. ${ }^{10}$ Theoretical knowledge concerns what is the case in the domain of nature: it is concerned with the sensible. The most basic epistemological lesson of the Critique of Pure Reason is that theoretical knowledge is limited to objects of possible experience: we cannot have theoretical knowledge about the supersensible. Hence we cannot determine that God exists, that the soul is immortal, or that the will really is free.

Practical knowledge, on the other hand, concerns the good to be brought about through action. It is in this context that Kant addresses the issue of freedom. We cannot invoke the notion of agency without invoking the notion of freedom. For if we take ourselves to be rightfully held responsible for what we do, then we must suppose that our agency is not brute force of nature; there must be some respect in which we are properly free from being determined by the causal order of material nature. We cannot make determinations about the good to be brought about through action if we do not conceive of ourselves as intentional agents, and this we can do only if we think of the supersensible. So as agents, we implicitly distinguish between the sensible and the supersensible. And yet, we cannot have theoretical knowledge of the supersensible. Hence we cannot introspect and determine of some particular action that it in fact results from the freedom that is proper to a rational being. The action may well have been the expression of some appropriately refined animal instinct - something that depends on sensuous inclination and answers to our desire to get on well in the sensible world. ${ }^{\text {II }}$

Practical knowledge concerns what ought to be done. If there is genuine knowledge to be had here, then the determination of what ought to be done must rest on objective grounds: it cannot be a matter of what a particular agent just happens to want. An objective determination of the good concerns what any rational being, in the unobstructed exercise of reason, would recognize as something that ought to be pursued. This is why Kant supposes that the fundamental principle of practical knowledge - the source of all knowledge about the good to be brought about through action - stems from reason alone, without regard to our existence as sensible

\footnotetext{
זo For Kant's distinction between theoretical and practical knowledge, see CPR Bix-x, A547-8/B575-6, A802/B830, and Kritik der praktischen Vernunft, KGS 5, Critique of Practical Reason, in Practical Philosophy, trans. and ed. Mary J. Gregor (Cambridge University Press, I996), 5:3-I4 and 89-I06 (CPrR).

${ }^{11}$ Kant makes this point often. See, for example, CPrR 5:28-30; CJ 5:275; CPR A802/B830; Grundlegung zur Metaphysik der Sitten, KGS 4, Groundwork of the Metaphysics of Morals, in Immanuel Kant, Practical Philosophy, 4:407 (G), and Die Religion innerhalb der Grenzen der bloßen Vernunft, KGS 6, Religion within the Boundaries of Mere Reason, in Immanuel Kant, Religion and Rational Theology, trans. and ed. Allen E. Wood and George Di Giovanni (Cambridge: Cambridge University Press, I996), 6:2 I-22, 3I, and 4I (R).
} 
beings in material nature. This principle is the moral law, which is expressed as an imperative binding categorically on finite rational beings. ${ }^{12}$

For the purposes of this chapter, it is necessary to grant Kant's (not uncontroversial) epistemological claim that the moral law, or categorical imperative, is the source of all knowledge about the good to be brought about through action. In establishing the moral law as the fundamental principle of pure practical reason, Kant abstracts from facts about the embodiment of reason in us. Kant's conception of the moral sublime emerges only after the categorical imperative is established, and the fact of our embodiment is brought back into view. Thus it is with the moral psychology of the rational animal that our account of the sublime resumes.

\section{THE SUBLIME VOCATION OF THE RATIONAL ANIMAL}

Kant, as we saw earlier, repeatedly suggests that there is something sublime about human nature: he speaks of our "sublime vocation" (CJ 5:264 and 262), the "sublimity of our moral vocation" (R 6:50; see also 6:22n), and "the sublimity of our nature (in its vocation)" (CPrR 5:87; cf. CPrR 5:I I7). To understand these remarks, we must bear in mind what we have just learned about Kant's distinction between the sensible and the supersensible. To recognize that one can be held responsible for what one does is to suppose that there must be some respect in which one is free from being determined by the causal order of material nature. And so, although we find ourselves in the sensible world, we must also think of ourselves as belonging somehow to a supersensible, or merely intelligible, order of reason.

When Kant talks about the "vocation" of our kind, the term he uses is Bestimmung. In logical contexts, this is commonly translated as "determination," in the sense that the judgment "this is green" represents the determination of a singular representation under the concept green. Likewise the Bestimmung of our species is what determines our species to be the species it is. Following ancient tradition, Kant conceives of our species as rational animal, with rationality being the determining feature. However, Kant also gives special emphasis to the point that no individual is perfectly or infallibly rational. Rationality may be our essence, but it is something to be cultivated and developed - as best we can, with an eye to an ideal with respect to which we always fall short. Hence Kant takes our "natural vocation" to consist in "continual progress toward the better"; ${ }^{13}$ the progress can only be continual because perfect rationality is unattainable. Hence the term Bestimmung takes on a normative and teleological sense in this context. ${ }^{\mathrm{I}}$ Our Bestimmung is a calling (vocation) to develop and express the rationality that is proper to our kind.

To understand Kant's claim that this vocation is itself sublime, it might help to consider the German term for the sublime, das Erhabene, which derives from the verb erheben, "to raise or lift up." Presumably, then, the vocation of the rational animal is "sublime" because it involves

${ }_{12}$ Strictly speaking, Kant distinguishes between the moral law as such from its formulation as an imperative binding categorically on all finite rational beings ( $\mathrm{G} 4: 4 \mathrm{I} 4$; CPrR 5:32-3). For present purposes, I speak of "the moral law" and "the categorical imperative" interchangeably. The categorical imperative is formulated as follows: "So act that the maxim of your will could always hold at the same time as a principle in a giving of universal law" (CPrR 5:30; see also G 4:402 and 42I, with alternate formulations at 42I, 429, and 438).

${ }_{13}$ Anthropologie in pragmatischer Hinsicht, KGS 7, Anthropology from a Pragmatic Point of View, trans. Robert B. Louden, in Anthropology, History, and Education, trans. and ed. Robert B. Louden and Günter Zöller (Cambridge: Cambridge University Press, 2007), 7:324 (Anth). To achieve consistency across Kant's texts when translating Bestimmung (and its cognates), I have modified the translation: Louden renders Naturbestimmung here as "natural destiny."

${ }^{14}$ See Reinhard Brandt, "The Guiding Idea of Kant's Anthropology and the Vocation of the Human Being," in Essays on Kant's Anthropology, ed. Brian Jacobs and Patrick Kain (Cambridge: Cambridge University Press, 2003), 85-I04, pp. 96-7. 
looking $u p$ to an ideal of perfect rationality and making the approximation of that ideal one's end. At the same time, we should now be able to make better sense of Kant's slightly different remarks, to the effect that the sublime is a state of mind that is distinguished by a certain attraction, or "feeling," for our "supersensible vocation" (CJ 5:257). The sublime is a state of mind in which we are uplifted, or oriented toward, what can only be conceived through reason alone, an ideal that must guide our conduct even though we could never recognize it (i.e., perfect virtue) in the flesh. ${ }^{15}$ Hence the sublime is a reflective state of mind, one in which the subject is somehow attuned to her condition, or predicament, as a rational animal.

Indeed, even our enjoyment of the sublime in nature - in which we obviously engage with some object in the world - is a reflective state of mind. Our appreciation of the sublime in nature begins with a physical comparison, be it of might or size. Peering out into the Grand Canyon, seeing eons etched into the countless ridges in the stone and the depths forged by the unceasing movement of water, we are aware of our relative spatiotemporal insignificance. We are lost in the comparison. And yet we are aware of our capacity, and readiness, to make this comparison - to accept our physical insignificance. What in us accepts this? Surely not our "sensible" or "animal" nature. The experience of the sublime points to something that remains unthreatened by the physical comparison. The subject must be ready to suppose that something in her survives the ravage, or eludes estimation by any spatiotemporal measure. Her attraction - that she lingers as she looks out over the precipice - points to something supersensible: her "intelligible" or "rational" nature. At the same time there is the competing claim - that element of repulsion, registering as the subject's fear that she will "disappear" in the comparison. When the canyon's open abyss arouses these contrasting movements of attraction and aversion, the mind is uplifted - sublime - only to the extent that the attraction holds sway.

\section{MORAL FEELING}

As we saw at the end of the section on the sublime in nature, Kant links our feeling for the sublime in nature with "moral feeling"; this suggests that one's readiness to linger over an open abyss might correlate with the development of one's capacity for moral feeling. But Kant does not say much about moral feeling in the Critique of the Power of Judgment, except to gloss it as "the feeling for (practical) ideas" (CJ 5:265), or "the feeling of a vocation of the mind that entirely oversteps the domain of [nature]" (CJ 5:268). Later, I explain why our enjoyment of the sublime in nature cannot quite involve moral feeling directly, but only something akin to it. First, however, we must examine Kant's account of moral feeling.

Kant defines moral feeling as "practically effected feeling": it is feeling that depends on, and arises from, a subject's representation of the moral law (CPrR 5:75). It is thus distinguished from "pathologically effected" feeling: that is, a feeling that "underlies all of our inclinations" and is produced by an object of the senses. Kant explains moral feeling through a developmental story; the background to this story is as follows. To come into one's reason is to be able freely to adopt certain ends. It is to be in a position to recognize that one does $x$ for the sake of $y$ - and thus to conceive of oneself, however dimly, as an agent. The rational subject represents her actions under rules: to act is to endorse, at least tacitly, a maxim or subjective principle of action. Now, it follows from Kant's view that the moral law is constitutive of practical, or will-determining, reason that when a subject comes into her reason she also has some tacit grasp - again, however dim - of the moral law. So, on the one hand, a rational agent cannot help having some appreciation of what morality requires, and conceiving of the good in a way that answers to the moral law. On the other hand, a rational animal is affected by sensuous desire

${ }_{15}$ On perfect virtue as an unattainable ideal, see CPrR 5:84 and Die Metaphysik der Sitten, KGS 6, The Metaphysics of Morals, in Practical Philosophy, 6:409 (MM). 
and inclination, so whatever promises to bring about or sustain her own well-being and comfort is liable to appear as something that ought to be pursued, or good. Thus a conflict is writ into human nature, expressed as competing conceptions of the good.

Moral feeling appears against the background of this conflict. Kant's story begins with "our pathologically determinable self," presuming that it is "our entire self" and thus trying "to make its claims primary and originally valid" (CPrR 5:74). The claim of the pathologically determinable self - the claim it takes to be "primary and originally valid" - is that some object of sensuous inclination ought to be pursued. Kant calls this "self-love." Self-love is perfectly natural, and even morally permissible: I may act out of self-love as long as it does not conflict with moral duty. ${ }^{16}$ However, self-love tends to outrun these limitations, giving rise to a certain illusion. A subject is liable to take sensuous inclination to be indicative of what is objectively good, when in fact it is indicative only of what appeals on the basis of her individual constitution and beliefs about the conditions of her own well-being. Kant calls the illusion that stems from self-love run amuck "self-conceit": it "prescribes as laws" - that is, as universally binding sources of the determination of the will - "the subjective conditions of self-love" (CPrR 5:74).

We should recall Kant's claim that someone who has come into the use of reason unavoidably has some consciousness (however $\mathrm{dim}$ ) of the moral law. This consciousness of the moral law "strikes down self-conceit" (CPrR 5:73), he claims, and "humiliates every human being when he compares it with the sensible propensity of his nature" (CPrR 5:74). Consciousness of a law binding on all rational beings as such "deprives self-love of its influence and self-conceit of its illusion"; it checks the tendency to treat subjective grounds of the determination of the will as objective and lawful. Moral feeling, or respect for the moral law, emerges as a reverential attraction to what makes us able to overcome the dominance of self-love, even though in point of fact it probably only momentarily "weakens" it (CPrR 5:73).

Kant takes moral feeling to be a natural endowment. This means that the rational animal who comes into the use of reason cannot help but enjoy some rudiment of moral feeling (MM 6:399). However, the capacity for moral feeling remains weak if left uncultivated, because the feeling itself is highly unstable: after all, it involves the subject's attraction to something that humiliates her, and humiliation is painful. Our capacity for moral feeling must be strengthened and made stable. To understand this point, let us consider how Kant recasts his claim about "respect for the moral law" in more concrete terms, namely, as respect for another human being. Kant writes:

Fontenelle says, "I bow before an eminent man, but my spirit does not bow." I can add: before a humble common man in whom I perceive uprightness of character in a higher degree than I am aware of in myself my spirit bows, whether I want it or whether I do not and hold my head ever so high, that he may not overlook my superior position. Why is this? His example holds before me a law that strikes down my self-conceit when I compare it with my conduct, and I see observance of that law and hence its practicability proved before me in fact. (CPR 5:76-7)

Let us suppose that I am aware of what morality requires of me, and, at least for the most part, I act accordingly - but occasionally I allow myself to suppose that my circumstances make this impossible. Now, in Kant's vignette, I am humiliated by a humble common man, someone of comparatively meager resources who, let us suppose, demonstrates the practicability of the duty of beneficence. His example affronts my attempt to excuse myself from its requirements. I am humbled by his example: "my spirit bows." Such humiliation is painful: I am averse to the example that this common man presents to me. As Kant notes, "we give way" to the feeling of respect "only reluctantly with regard to a human being" (CPrR 5:77). I will likely want to gratify my feeling of aversion, perhaps by magnifying some previously overlooked character flaw, or

${ }^{16}$ This is what Kant refers to as "rational self-love" (CPrR 5:73). 
perhaps by projecting a false one onto his image. If I do this, I extinguish the feeling of respect. I must not recoil from this humiliation if I am to sustain the feeling of respect.

To see how the recoil might be avoided, let us examine Kant's vignette more closely. We should note that I am actually humiliated not by the man but rather by the moral law itself. ${ }^{17}$ Kant is careful to present the vignette so that no external humiliation is involved; every social convention has been observed. So "my spirit bows" while my head remains high. The humiliation, rather, is internal.

The idea of an internal humiliation deserves further examination. We tend to think of humiliation as hitting from outside: I am humiliated by someone or something without. Humiliation is typically external, in other words. So we should press on this idea of an internal humiliation that is, on the idea that the moral law "unavoidably humiliates every human being" (CPrR 5:74). Because Kant supposes that the moral law is constitutive of rational agency, or of what it is to be a rational being with a will, it does not seem correct that the moral law can humiliate a rational being, at least if we suppose that humiliation has an external origin. Kant's point, however, is that this humiliation rests on a moral illusion: it is how things look if the subject takes herself to be principally a "sensible," rather than a "rational," being. Recall that Kant's account of moral feeling began with the episode in which our "pathologically determinable self" supposes that it is "our entire self" (CPrR 5:74). A person who more readily identifies with her "pathologically determinable self" is more liable to gratify the aversion that springs from the pain of humiliation. Such a person cannot sustain moral feeling and in turn avoids comparing her conduct against the standard of the moral law. All of this follows from her self-conception, from the supposition that she just is her "pathologically determinable self."

According to Kant, even a person of sound moral disposition will experience resistance to the moral law. But the person of sound moral disposition does not gratify this aversion quite so readily, because the moral law does not seem to impinge on her from outside. This allows the attractive aspect of respect to dominate, so that it can be sustained: "[O]nce one has laid selfconceit aside and allowed practical influence to that respect, one can in turn never get enough of contemplating the majesty of this law, and the soul believes itself elevated in proportion as it sees the holy law elevated above itself and its frail nature" (CPrR 5:77, translation altered). To "lay self-conceit aside" is to give up supposing that one maintains oneself by acting from selflove as an unconditional maxim. Put in positive terms, it is to think of oneself as principally a rational being that is to be respected, rather than as principally a sensible being to be preserved. The individual who can sustain a feeling of respect has this self-conception, and this enables her to look up to the "majesty" of the moral law without experiencing it as an oppression raining down on her from without. ${ }^{18}$

Because Kant does not suppose that we can arrive at a state of character where we experience no resistance to moral duty, there is always an element of resistance in moral feeling. Aversion is a basic ingredient. And even though the capacity for moral feeling is a natural endowment of our species, such feeling cannot so much as register in one's consciousness if it is not sustained. The ability to sustain a feeling of respect requires that the attractive aspect effectively determine the subject's mental state. And this, in turn, rests on the subject's selfconception: she must conceive of herself, by essence and by calling, as a rational being. If this

${ }_{17}$ On this point, see Allen W. Wood, "Self-Love, Self-Benevolence, and Self-Conceit," in Kant, Aristotle, and the Stoics, ed. Stephen Engstrom and Jennifer Whiting (Cambridge: Cambridge University Press, I996), I4I-6I.

${ }^{18}$ See Andrews Reath, "Kant's Theory of Moral Sensibility," Kant Studien 80 (I989), 284-302, who points out the danger of supposing that, for Kant, the attraction to the ideal represented in the moral law mechanically interacts with the attractions of happiness, so that the stronger of two affective forces wins out (as in a Humean philosophy of mind). "The appropriate metaphor," Reath writes, "is rather that of a struggle between two parties for something like legal authority or political legitimacy" (289n I3; see also 296). 
orientation toward her vocation as a rational being is firm, then the feeling of respect can be sustained. For only then will the subject take pleasure in recognizing that there is something in her that has the capacity to resist the claims of her sensible nature.

\section{MORAL FEELING AND THE SUBLIME}

Now that we have considered Kant's view of moral feeling, it is time to address its relation to the sublime. There is plenty of circumstantial evidence in the Critique of Practical Reason to support the claim that Kant saw a connection between moral feeling and the sublime. Once Kant concludes his account of respect in chapter III of the Analytic of Pure Practical Reason (around CPrR 5:8I), the remainder of the chapter dances around the topic of the sublime in one way or another. First, Kant denies that morality is like beauty - something pleasant and gentle, which we would enter into without any feeling of aversion - and hints instead that it is like the sublime, in that there is always an element of aversion (CPrR 5:82-4; see also CJ 5:27I). Then Kant follows with an encomium to the sublimity of duty - sublime due to its source in what "elevates a human being above himself (as a part of the sensible world)" (CPrR 5:86).

But we need to understand the connection between moral feeling and the sublime and not simply note Kant's hints about it. To address this issue, it will help to recognize that not every "uplifted" state of mind is genuinely sublime by Kant's lights. In the Critique of the Power of Judgment, Kant points to enthusiasm as an example, which he glosses as "the idea of the good with affect" (CJ 5:272). Affect is overwhelming feeling that renders the subject "incapable of engaging in free consideration of principles, in order to determine itself in accordance with them" (CJ 5:272). ${ }^{19}$ Someone might, for example, be overcome during a political speech; this could be "uplifting" if she finds herself longing for certain ideals. But if we do not understand what we seek, and why it is good, then we are not freely aiming at anything at all: it is the sweep of affect that urges us on, and we are chasing an image.

For this reason, Kant takes enthusiasm to be a fraudulent mode of the sublime; he first says that it merely "seems to be sublime," before clarifying that it is "aesthetically sublime" (CPrR 5:272). This specification is somewhat jarring, because we are left wondering how it relates to the aesthetic judgment regarding the sublime in nature (which I consider in the following). But Kant's point presumably rests on a distinction he often draws between aesthesis and logos, that is, between what has its source in our receptivity versus what has its source in the spontaneity of our reason. Enthusiasm is aesthetically sublime in the sense that the mind is "uplifted" through affect, something that is brought on the subject from without and renders her momentarily incapable of rational reflection on principles. What is aesthetically sublime in this sense works us over, inducing an "agreeable exhaustion" that Kant likens to having one's muscles and joints worked over by a masseur (CJ 5:273-4). It does not exercise the freedom that is proper to a rational being..$^{20}$ The Kantian sublime - the sublime that Kant endorses and takes up under the banner of critical philosophy - can be distinguished as the "logical" sublime in the sense that it depends on the subject's consciousness of rational principles. Moral feeling is a mode of the Kantian sublime: it is an elevated state of mind, registering as the subject's attraction to an ideal

${ }_{19}$ Kant discusses affect (Affekt) at length and distinguishes it from passion (Leidenschaft); see CJ 5:272n; MM 6: 407-9; and Anth 7:25I-65.

${ }^{20}$ For an opposing interpretation of the sense in which enthusiasm is "aesthetically sublime," see Robert R. Clewis, The Kantian Sublime and the Revelation of Freedom (Cambridge: Cambridge University Press, 2009). For a discussion of the problems with Clewis's interpretation, see Melissa McBay Merritt, review of Robert Clewis, The Kantian Sublime and the Revelation of Freedom, British Journal for the History of Philosophy I8, 3 (2010), 529-32. 


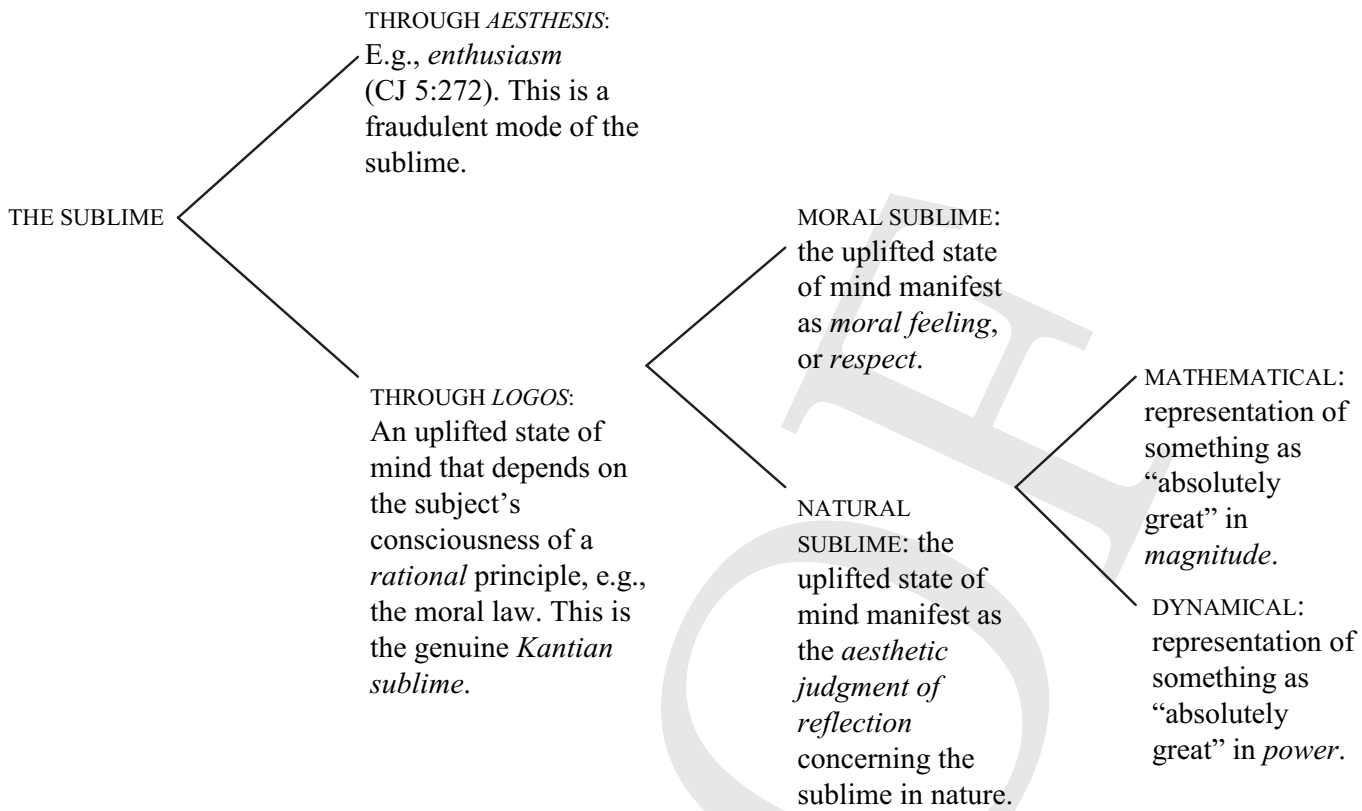

FIGURE 3.I. Modes of the sublime.

conceived through the moral law. As we will see in the next section, even one's enjoyment of the sublimity of the Grand Canyon is sublime in the "logical" sense that Kant endorses. Kant's taxonomy of terms can be summarized in Figure 3.I.

\section{ADMIRATION AND RESPECT}

In order to assess the relation between the moral and the natural sublime, it will help to distinguish them more clearly. We can do this by specifying the feeling operative in each. According to Kant, the sublime can be made manifest either through admiration (Bewunderung) or through respect (Achtung) (CJ 5:245). Kant distinguishes these feelings first by their proper objects: the proper object of respect is the moral law, or persons inasmuch as they may figure as "examples" of this law; the proper object of admiration, by contrast, is some thing, "for example, lofty mountains, the magnitude, number, and distance of the heavenly bodies, the strength and swiftness of many animals" (CPrR 5:76). Thus Kant implies that the moral sublime is experienced as respect, or moral feeling, whereas the natural sublime is experienced as admiration.

Kant claims that admiration is "analogous" to the feeling of respect (CPrR 5:78). Both feelings require the subject to conceive of an absolute standard, something against which everything else falls short. The difference is that the subject who feels respect conceives of a standard that she recognizes as holding for herself. Recall the respect I feel for the "humble common man" in our earlier example. The man's example enables me to represent the moral law in all of its "purity": I see that this law commands categorically, without granting an exception for me on the basis of my circumstances, which have been shown to be comparatively favorable at that. His example, or rather my respect for it, exhorts me to practice greater beneficence. Now consider the other feeling. I watch Olympic gymnastics in a state of astonished admiration. The athletes seem stronger, faster, and more dexterous than any I can imagine. Yet they do not serve as "examples" of a law, or a standard, that I give to myself. I do not share their end: I do not get 
up off the couch and begin to stretch or jump. ${ }^{21}$ I admire their skill, but it would be delusional for me to respect it.

Admiration, then, is contemplative, whereas respect is exhortative. If, as I have argued, the natural sublime is enjoyed through admiration, whereas the moral sublime is enjoyed through respect, then it would follow that our appreciation of the sublime in nature is merely contemplative. And indeed, this conclusion is supported by Kant's view that we make a "pure aesthetic judgment" when we enjoy the sublime in nature. An aesthetic judgment is one that is determined by a feeling of pleasure or pain; by this it is distinguished from a logical judgment, which is determined by a concept or a rule. Hence the aesthetic judgment on the sublime in nature does not directly involve the concept of the moral good. Our enjoyment of the sublime in nature is morally indeterminate. It is, in this regard, merely contemplative: it does not directly exhort me to develop moral character, or cultivate my capacity for moral feeling. ${ }^{22}$

Still, Kant insists that our capacity to enjoy the sublime in nature "has its foundation in human nature," and, more specifically, in our propensity for moral feeling (CJ 5:262 and 265). The cultivation of this propensity "remains our responsibility" (CJ 5:262), and without it we would be unable to enjoy the sublime in nature (CJ 5:265). As I have argued, the requisite moral development turns on the subject's recognition that she is by nature and by calling a rational being. Only with this self-conception can the subject avoid being overwhelmed by the feeling of aversion that is an essential ingredient of the sublime. Thus the enjoyment of the sublime in nature depends not only on a background consciousness of the moral good but also on the particular power of one's attraction to it.

\section{CONCLUSION}

It is worth considering, in closing, how Kant's theory of the sublime develops from his 1764 Observations on the Feeling of the Beautiful and the Sublime to his mature view in the critical period. In the early work, Kant claims that the sublime "stretches the powers of the mind more forcefully" than the beautiful; it is exhausting and so must be sweetened by a certain measure of beauty in order to be endured by the subject. ${ }^{23}$ To some extent, the mature Kant continues this theme, inasmuch as he conceives of the sublime in terms of an arousal of contrasting impulses of the mind: surely particular individuals will become quickly exhausted by such a state of mind. Thus it is all the more striking that, in one of the most memorable passages of Kant's critical philosophy, we find talk of a sublime state of mind that is not inherently exhausting:

Two things fill the mind with ever new and increasing admiration and reverence, the more often and more steadily one reflects upon them: the starry heavens above me and the moral law within me.... The first view of a countless multitude of worlds annihilates, as it were, my importance as an animal creature... The second, on the contrary, infinitely raises my worth as an intelligence by my personality, in which the moral law reveals to me a life independent of animality and even of the whole sensible world. (CPrR 5:I6I-2)

${ }^{21}$ Kant makes the related point when he imagines a "true scholar" who respects Voltaire "at least with regard to his talents"; both share the end of learning, and so the scholar measures himself against the standard that Voltaire putatively exemplifies. But by contrast the "common" admirer (a dilettantish Enlightenment enthusiast, perhaps) "gives up all respect" for Voltaire with the belief that he has "somehow learned [his] badness of character" (CPrR $5: 78)$.

${ }^{22}$ My point about the merely contemplative quality of the natural sublime could be strengthened by taking note of the "disinterested" quality of the pleasure that is proper to pure aesthetic judgment.

${ }_{23}$ Beobachtungen über das Gefühl des Schönen und Erhabenen, KGS 2, Observations on the Feeling of the Beautiful and Sublime, in Observations on the Feeling of the Beautiful and Sublime and Other Writings, ed. and trans. Patrick Frierson and Paul Guyer (Cambridge: Cambridge University Press, 20I I), 2:2 I I (OBS). Cf. Anth 7:243. 
Kant points here to a sublimity of mind that gathers strength the more it is sustained. Now, the crucial difference between Kant's early and mature theories of the sublime revolves around the issue of the moral source of sublimity. In the early work, the connection between morality and the sublime is drawn tenuously at best. ${ }^{24}$ Kant's mature view, by contrast, is that our capacity to appreciate the sublime in nature is grounded in the development of sound moral disposition. Presumably, then, the sublime is not exhausting for someone of sound moral disposition. And if Kant takes the cultivation of sound moral disposition to be the proper end of a rational animal - its "natural vocation" - then we can be sure that the sublime and its connection to morality is not a peripheral curiosity for Kant. It runs, rather, to the very heart of his critical philosophy.

24 Some commentators have tended to exaggerate the extent to which Kant draws a connection between the sublime and morality in the precritical Observations. See, for example, John Zammito The Genesis of Kant's Critique of Judgment (Chicago: University of Chicago Press, I992), 3I-32 and 276, and Clewis, The Kantian Sublime, I3. Kant is actually casual about the connection in the Observations: he singles out "true virtue" as the only "moral quality" that is properly called "sublime" but evinces greater interest in the idea (reminiscent of British moral sense theory) that sympathy is "beautiful and loveable" (OBS 2:215). 